\title{
Quality Costs in Improving the Efficiency Production Costs:
}

\author{
A Case Study in Beverage Company, Bandung, Indonesia
}

\author{
Riauli Susilawaty Hutapea*, Savitri Nirmalasari Dewi, Carolina M. Lasambouw \\ Accounting Department \\ Bandung State of Polytechnic \\ Bandung, Indonesia \\ *riauli.susilawati@polban.ac.id, savitri.nirmalasai.akun16@polban.ac.id, carolina.magdalena@polban.ac.id
}

\begin{abstract}
Beverage Technic is a manufacturing company engaged in the machinery and food industry. Activities undertaken by Beverage Technic in the food and beverage division are processing the main ingredients of ginger and other supporting materials to become a finished product in the form of traditional instant drinks ready to be sold or distributed. This final project report focuses on applying quality costs in improving the efficiency of production costs in the Beverage Technic. This study aims to determine whether the Company has implemented and reported quality costs and whether the application of quality costs can improve production costs at the Company. The method used in this research is to use a descriptive analysis method with a case study approach by comparing and expressing the problems that exist with data collection through interviews, documentation, and observation. Based on the research result on Beverage Technic, the Company has not recorded quality costs consistently, so that costs incurred for product quality are difficult to track. Then the high costs for product quality make production costs too high. The quality costs incurred by the Company reached $4.03 \%$ of total sales.
\end{abstract}

Keywords-beverage technic, production cost efficiency, application of quality costs

\section{INTRODUCTION}

In this era of globalization, companies are required to compete with each other well and healthily. In this era, competencies are getting tighter and impacting companies to improve their products' quality to achieve customer satisfaction. Improving product quality cannot be achieved with an easy process without the optimal effort and thought to achieve innovative ideas. Besides, the Company is also required to achieve optimal profits. The effort made by management in achieving optimal profit is by implementing several plans, methods, or ways to achieve these goals.

To maintain optimal operational and planning activities, the Company must make steady improvements. Companies must compete with other companies by making improvements in terms of product excellence with other products. Product excellence in quality, attractive design/packaging, price discounts, or the best possible service. Companies are required to expand sales to reach overseas. By expanding its sales, the Company needs to improve product quality. Therefore, it is necessary to increase product quality standards to provide the best quality and following consumer desires. With increasing standards, companies can also compete with other companies with confidence. An increase in quality will also prevent the Company from losses due to damaged or inferior products.

Improving product quality will encourage companies to increase marketing expansion and product distribution to compete with other competitors. With the increase in quality, the Company can maintain its sustainability, and the Company's profit will increase. If the Company ignores the product's quality, the Company will suffer losses, and the costs incurred will be even more significant due to damaged or nonconforming product standards. Cost reduction due to product quality will increase company profits. Therefore, increasing product quality regularly will minimize the Company's loss.

Improved product quality control can reduce quality costs so that company profits can increase and reduce excess production costs. Regular supervision of product quality can prevent the emergence of products that are not under standards that will make production costs more efficient. Companies do not have to reduce the selling price due to defective products and do not need to repair or rework defective products. So, the materials that can efficiently use and production costs decrease, such as raw materials and labor.

A quality costing system can become an excellent tool in the overall management of a business. It can indicate the health of management performance in many areas of the organization. Measurements of quality-related costs also reveal shortcomings in cost allocation, standards, procedures, and practices, which may remain undetected by the more commonly used production/operation and labor-based analysis [1].

Beverage Technic is a manufacturing company engaged in the food and machinery industry. The Company's food and beverage division activities are to process the main ingredients 
of ginger and other supporting materials to become a finished product in traditional instant drinks ready to be sold or distributed. The marketing of this beverage product is wide enough for various regions. Even the beverage product has been available in minimarkets. Therefore improving the quality of this Company is needed to maintain competition with other competitors.

Improving product quality is very important to the Company because product quality is very influential in increasing sales. Based on an interview with one of the staff at Beverage Technic, the Company has not consistently recorded quality costs. The costs incurred for product quality are difficult to track. Then the high cost for product quality makes production costs high and inefficient. Defective product companies have increased due to errors when packaging in the form of torn packaging that affects its quality. Besides, employees often make mistakes during the packaging process, which results in companies having to rework the product. Also, the Company has not explicitly applied to the quality costs appropriately. The Company's quality costs hide in the overhead items, so a separate report needs to develop. Therefore this Company needs to set quality reporting and reporting costs.

\section{THEORETICAL BASIS}

\section{A. Definition of Quality Costs}

Quality Cost is a measure of the costs specifically associated with the achievement or non-achievement of product or service quality. They would represent the difference between the actual cost of a product or service and the reduced cost if there were no possibility of substandard service, failure of products, or defects in their manufacture [1].

\section{B. Types of Quality Costs} [2]:

Hansen and Mowen classifies the quality costs as follows

- Prevention costs incurred to prevent low quality in the product or service produced. As prevention costs increase, we expect failure costs to decrease. Examples of prevention costs are quality engineering, quality training programs, quality planning, quality reporting, supplier evaluation and selection, quality audits, quality circles, field trials, and design reviews.

- Valuation costs are to determine whether products and services are suitable for their needs or customer needs. Examples include checking and testing materials, packaging inspections, overseeing assessment activities, product acceptance, process acceptance, measurement equipment (inspection and testing), and external certification.

- Internal failure costs occur because products and services do not meet customer specifications or needs before sending it to outside parties. This condition is a failure detected by the assessment activity. Examples of internal failure costs are scrap, rework, downtime (due to defects), re-inspection, retesting, and design changes This fee is lost if there are no defects.

- External failure costs occur because products and services fail to meet requirements or meet customer needs after being sent to the customer. Of all the quality costs, this category can be the most devastating. Withdrawal fees, for example, can reach hundreds of millions of dollars. Other examples include sales lost due to low product performance, returns, and benefits due to poor quality, guarantees, repairs, product liabilities, customer dissatisfaction, loss of market share, and complaint adjustments. External failure costs, such as internal failure costs, are lost if there are no defects [2].

\section{Size / Quality Aspects}

One of the most effective tools for evaluating a quality management program's success is measuring quality costs [3].

According to Fandy (in Nasution) argues that according to quality experts, a company with a quality management program that runs well, the quality cost is not more than $2.5 \%$ of sales. Each Company can prepare a budget to determine the standard quality costs of each group or element individually. The total quality costs budgeted are no more than $2.5 \%$ of sales. Companies must identify the behaviour of each cost quality element to achieve the standard. Some quality costs vary with sales, but others do not. The following points need to consider in order for a quality performance report [4].

\section{Cost of Quality as an Indicator of Quality}

According to Nasution [4], Schiffauerova and Thomson [5], some world-class companies use quality cost measures as indicators of the success of quality improvement programs can be related to the following measures.

- Quality costs compared to sales value (percentage of total quality costs to sales value). The lower this value indicates, the more successful the quality improvement program is.

- Quality costs compared to profits (percentage of total quality costs to the value of profits). The lower this value indicates, the more successful the quality improvement program is.

- Quality costs compared the cost of goods sold, measured by the percentage of total quality costs to the goods sold. The lower value indicates the quality improvement program's success [5].

\section{E. Definition and Elements of Production Costs}

Production costs are divide into direct raw material costs, direct labor costs, and factory overhead costs. 


\section{F. Relationship with Quality Cost Efficiency}

The reduction in defective product units means that only a few raw materials and labour are needed to produce the same output. Improving product quality can reduce the number of defective product units, but the number of inputs used can increase production efficiency. By optimizing quality control, quality costs can be reduced/minimized and affect production costs. The production costs become efficient if using the entire entered input and nil residual. However, if the output produced does not meet quality standards, it requires reworking the product to be sold [2].

\section{G. Benefits of Quality Cost Information}

According to Garrison et al., the benefits of quality cost information are [6]:

- Quality cost information helps managers see the financial benefits of defects. Managers are usually not aware of the high cost of their quality because they cross departmental boundaries and cannot track and accumulated naturally by the cost system. Therefore, when first presented with a quality cost report, managers are often surprised by the costs caused by low quality.

- Quality cost information helps managers identify the importance of quality problems facing the Company. For example, a quality cost report can show that residual material is a significant quality problem or that the Company incurred a large number of warranty costs. With this information in place, managers have a better idea of where to focus their business.

- Quality cost information helps managers see whether quality costs in their Company are poorly distributing. Generally, quality costs should be more distributed towards prevention and assessment activities and less directed towards failure [6].

\section{RESEARCH METHODS}

\section{A. Type of Research}

This research conducted using the descriptive analysis method on the Company, so this research aims to describe and interpret something or, in this case, to provide a detailed description of the application of quality costs in improving the efficiency of production costs.

\section{B. Data Analysis Tools}

- Researchers collected data through interviews, documentation, and observation at Beverage Technic.

- Analyzing data begins by grouping costs included in the quality cost element in the report on production costs. Then do a quality cost calculation.
- Next, the researcher will compare each quality cost element with total sales using a significant percentage of quality cost using the formula:

$$
\text { Percentage of quality cost }=\frac{\text { Quality Cost }}{\text { Total Sales }} x 100 \%
$$

- Furthermore, analysis and reporting of quality costs are carried out - conclusions drawn from the analysis results related to quality costs in improving production costs' efficiency.

\section{Types and Sources of Data}

The data types in this study are subject and documentary data. Data sources used in this study are primary and secondary data. The data used are production cost report data, sales data, all costs related to product quality.

\section{RESULTS AND DISCUSSION}

\section{A. Results}

\section{1) Company production costs}

TABLE I. REPORT ON PRODUCTION COSTS IN 2017

\begin{tabular}{|l|l|}
\hline \multicolumn{2}{|c|}{$\begin{array}{c}\text { CV. Cihanjuang Inti Teknik } \\
\text { Cost of Goods Overview in 2017 }\end{array}$} \\
\hline \multicolumn{2}{|c|}{ IDR } \\
\hline $\begin{array}{l}\text { Initial inventory of raw and auxiliary } \\
\text { materials (01/01/2017) }\end{array}$ & 2.540 .000 .000 \\
\hline $\begin{array}{l}\text { Purchase of raw and auxiliary materials } \\
\text { during 2017 }\end{array}$ & 1.173 .368 .925 \\
\hline The raw and auxiliary materials available & 3.713 .368 .925 \\
\hline $\begin{array}{l}\text { Final inventory of raw and auxiliary } \\
\text { materials (31/12/2017) }\end{array}$ & -3.421 .103 .750 \\
\hline The raw and auxiliary materials used & \\
\hline Direct wage costs & \\
\hline Factory overhead costs: & 76.000 .000 \\
\hline Production supervisor costs & 45.000 .000 \\
\hline Indirect labor costs & 10.500 .000 \\
\hline Training costs & 1.250 .000 \\
\hline Maintenance and repair costs of machines & 6.000 .000 \\
\hline $\begin{array}{l}\text { Maintenance and repair costs of the } \\
\text { building }\end{array}$ & 8.902 .265 .175 \\
\hline Initial testing costs of raw materials & 8.900 .000 \\
\hline Repacking costs & 70.080 .000 \\
\hline Electricity cost & 3.495 .563 \\
\hline Depreciation cost of the machine & 750.000 \\
\hline Equipment depreciation costs & 27.935 .463 \\
\hline Depreciation expense for the building & 3.720 .000 \\
\hline Handling of raw materials & 15.800 .000 \\
\hline Product inspection & 5.000 .000 \\
\hline $\begin{array}{l}\text { Maintenance workforce and machine } \\
\text { repair }\end{array}$ & 25.000 .000 \\
\hline Rework & 2.531 .241 .355 \\
\hline Total of overhead costs & -2.052 .500 .000 \\
\hline Factory cost of goods & 339.173 .092 \\
\hline Initial inventory of work in progress \\
\hline Final inventory of work in progress \\
\hline Cost of goods sold & \\
\hline \multicolumn{2}{|c|}{} \\
\hline
\end{tabular}

Source: CV. Cihanjuang Inti Teknik.

Based on Table 1, the report on production costs in 2017, the total raw material costs incurred by the Company amounted to Rp.292,265,175.00 consisting of Ginger, Palm Sugar, White 
Sugar, Creamers, and other spices. Direct labour costs incurred by the Company in 2017 amounted to Rp1,715,499,580.00, consisting of around 54 employees and six people as production supervisors or forepersons of IDR76,000,000.00. As for the indirect labour costs incurred in the amount of IDR45,000,000.00 for three employees. The overhead costs incurred during 2017 amounted to IDR 339,173,092.00.

The Company maintains machinery and warehouse regularly every month. The place used to store finished products can be kept clean from damaged products due to leakage dirty. That year, there were training costs used for employees who received special courses for the packaging process, which were even more attractive to maintain consumer interest in terms of packaging.

2) Company quality costs: Measuring the quality cost in the small-scale industry is very important and useful. It helps to identify the specific quality levels and ultimately improves quality. The total quality costs reduce in line with the implementation of the quality cost system. Regarding these quality costs, there is a robust negative co-relation between prevention costs and internal failure costs. This result implies that we should direct more efforts towards prevention activities so as reduce internal failure costs.

3) Classification of quality costs: As discussed in the previous literature review, four quality costs categories are prevention costs, estimated costs, internal failure costs, and external failure costs [7]. Classification of quality costs aims to control the Company's quality of the product to be more effective as follows [7]:

a) Prevention of costs: Costs incurred in preventing product quality defects, such as quality training costs, maintenance costs. The costs incurred at Beverage Technic in 2017 include training costs, maintenance, repair costs, warehouse maintenance and repair costs, and maintenance and repair labour costs

b) Valuation fees: Costs incurred to find or detect errors that occur, such as test fees, checking fees. Estimated costs incurred in 2017 on the Beverage Technic. This technique includes the cost of production supervisors, the cost of Initial Testing of raw materials, and the cost of product inspection.

c) Internal failure costs: Costs incurred due to damage before the product reaches the customer, such as the cost of correction, reworking, and processing costs. The cost of internal failures that occurred in 2017 in the Beverage Technic includes costs of handling raw materials, the cost of reworking, and repacking costs.

d) External failure costs: Costs are incurred due to a defective or damaged product after the product reaches the customer. There are no external failure costs in Beverage Technic because the Company does not receive returns from the sale of goods because it is a food product. After the product packaging open, it cannot return [7].
4) Calculation of quality costs: After classifying quality costs, the next step is to calculate the quality costs incurred in the company that aims to identify that the costs incurred by the company for quality improvement are efficient or not. These costs will then be calculated based on classification and calculated the percentage by comparing the total cost of quality with sales. Based on the costs obtained in 2017, the quality costs that can be calculated are as follows:

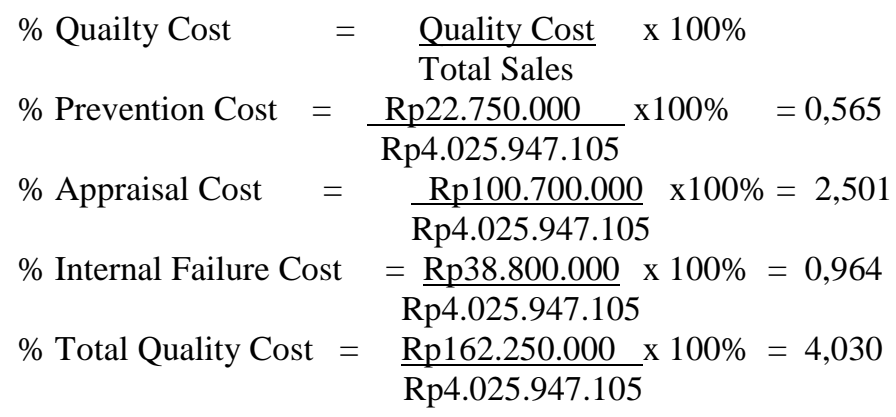

On the questionnaire, the report of the quality cost components is in euros in absolute terms. We standardize them for most of our analysis by dividing them by the sales volume. On average, total quality cost sums up to $2,59 \%$ of sales [8].

Measurement or calculation can be useful for companies in providing an overview of the cost of quality incurred and the actual quality.

Based on the quality cost report above, the total quality cost in 2017 was IDR 162,250,000.00, with a $4.03 \%$ percentage. Consists of Prevention Costs of IDR 22,750,000.00 with a percentage of $0.57 \%$. Appraisal fees of IDR100,700,000.00 with a percentage of $2.5 \%$, and an internal failure fee of IDR $38,800,000.00$ with a percentage of $0.96 \%$. So that the total quality cost of IDR. 162,250,000.00 with a percentage of $4.03 \%$.

Based on the calculations, the amount of quality costs is $4.03 \%$. In contrast, according to some experts, the percentage of quality costs is not recommended to exceed $2.5 \%$ of total sales, so that the costs incurred by the Company in 2017 for product quality are too high. Besides, the percentage distance from the classification of quality costs above is very far away. Based on these calculations, the percentage of valuation costs is higher than the other components, namely $2.5 \%$. The high percentage of valuation costs shows that the Company relies heavily on estimation or valuation to maintain its quality. So that assessments or estimates by companies tend to only rely on the final assessment of products produced according to standards or not while product mismatches or defects often do occur in the Company for one reason or another.

\section{B. Discussion}

Based on the research results on the Beverage Technic, it has implemented quality costs but has not yet reported quality costs individually. The measure of the quality of a product 
following the actual costs incurred. The Company has its standards or conditions in maintaining its quality. Quality costs are costs whose size is relatively dependent on the comparison.

Based on the calculations obtained previously, the percentage of quality costs is above $2.5 \%$, and then researchers estimate the quality costs. The following is an estimated table for 2017 :

$$
\begin{aligned}
& \% \text { Quailty Cost } \quad=\quad \text { Quality Cost } \times 100 \% \\
& \text { Total Sales } \\
& \% \text { Prevention Cost }=\underline{\operatorname{Rp} 41.750 .000} \times 100 \%=1,037 \\
& \text { Rp4.025.947.105 } \\
& \% \text { Appraisal Cost } \quad=\frac{\operatorname{Rp} 27.300,000}{\operatorname{Rp} 4.025 .947 .105} \times 100 \%=0,678 \\
& \% \text { Internal Failure Cost }=\underline{\operatorname{Rp} 17.800 .000} \times 100 \%=0,442 \\
& \text { Rp4.025.947.105 } \\
& \% \text { Total Cost Quality }=\underline{\operatorname{Rp} 86.850 .000} \times 100 \%=2,157 \\
& \text { Rp4.025.947.105 }
\end{aligned}
$$

\begin{tabular}{|c|c|c|}
\hline \multicolumn{3}{|c|}{ Estimated Quality Cost in 2017} \\
\hline Item & Total (IDR) & Percentage \\
\hline Total sales & 4.025.947.105 & \\
\hline \multicolumn{3}{|l|}{ Prevention costs } \\
\hline Training costs & 29.500 .000 & 0,73 \\
\hline $\begin{array}{l}\text { Maintenance and repair costs of } \\
\text { machines }\end{array}$ & 1.250 .000 & 0,04 \\
\hline $\begin{array}{l}\text { Maintenance and repair costs of } \\
\text { the building }\end{array}$ & 6.000 .000 & 0,15 \\
\hline $\begin{array}{l}\text { Maintenance workforce } \quad \text { and } \\
\text { machine repair }\end{array}$ & 5.000 .000 & 0,12 \\
\hline Total of prevention costs & 41.750.000 & 1,04 \\
\hline \multicolumn{3}{|l|}{ Appraisal costs } \\
\hline Production supervisor costs & 19.000 .000 & 0,47 \\
\hline $\begin{array}{l}\text { Initial testing costs of raw } \\
\text { materials }\end{array}$ & 2.500 .000 & 0,06 \\
\hline Product inspection costs & 5.800 .000 & 0,14 \\
\hline Total of appraisal cost & 27.300.000 & 0,68 \\
\hline \multicolumn{3}{|l|}{ Internal failure costs } \\
\hline Handling of raw materials & 3.720 .000 & 0,09 \\
\hline Repacking costs & 6.080 .000 & 0,15 \\
\hline Rework costs & 8.000 .000 & 0,20 \\
\hline Total of internal failure costs & 17.800.000 & 0,44 \\
\hline Total of quality costs & 86.850 .000 & 2,16 \\
\hline
\end{tabular}

TABLE II. CALCULATION OF THE ESTIMATED QUALITY COSTS PERFORMED ON THE BEVERAGE TECHNIC IN 2017

Based on Table 2, the results of the calculation of the estimated quality costs performed on the Beverage Technic in 2017, made a reduction in quality costs incurred during the year, namely reducing the cost of production supervisors, the cost of product inspection, the cost of initial testing of raw materials, the cost of repacking, and the cost of reworking. An additional training fee of IDR. 19,000,000 was made. The estimated cost of quality is done based on considerations that occur in the field. The real problem lies in the imposition of supervisory production costs that are too high and therefore required to reduce labour. Too many employees reduce the production workforce during the production process, and some employees do not carry out effective supervision.

Based on the results of the estimated costs incurred by the Company emphasized the cost of prevention and assessment so that the Company can avoid the cost of failure. The Company's prevention cost focuses on preventing the Company's

\begin{tabular}{|c|c|c|}
\hline \multicolumn{3}{|c|}{ Comparison of the Actual and Estimated Quality Cost in 2017} \\
\hline Item & Actual & Estimated \\
\hline \multicolumn{3}{|l|}{ Total sales } \\
\hline \multicolumn{3}{|l|}{ Prevention costs } \\
\hline Training costs & 0,26 & 0,73 \\
\hline $\begin{array}{l}\text { Maintenance and repair costs of } \\
\text { machines }\end{array}$ & 0,04 & 0,04 \\
\hline $\begin{array}{l}\text { Maintenance and repair costs of } \\
\text { the building }\end{array}$ & 0,15 & 0,15 \\
\hline $\begin{array}{l}\text { Maintenance workforce and } \\
\text { machine repair }\end{array}$ & 0,12 & 0,12 \\
\hline Total of prevention costs & $\mathbf{0 , 5 7}$ & 1,04 \\
\hline \multicolumn{3}{|l|}{ Appraisal costs } \\
\hline Production supervisor costs & 1,89 & 0,47 \\
\hline $\begin{array}{l}\text { Initial testing costs of raw } \\
\text { materials }\end{array}$ & 0,22 & 0,06 \\
\hline Product inspection costs & 0,39 & 0,14 \\
\hline Total of appraisal cost & 2,50 & 0,68 \\
\hline \multicolumn{3}{|l|}{ Internal failure costs } \\
\hline Handling of raw materials & 0,09 & 0,09 \\
\hline Repacking costs & 0,25 & 0,15 \\
\hline Rework costs & 0,62 & 0,20 \\
\hline Total of internal failure costs & $\mathbf{0 , 9 6}$ & $\mathbf{0 , 4 4}$ \\
\hline Total of quality costs & 4,03 & 2,16 \\
\hline
\end{tabular}
workforce from mistakes or mistakes made by training to increase employees' skills. The appraisal cost is an appraisal made on machinery such as maintenance and repair of raw materials issued by the Company. Therefore, here is a comparison of the actual and estimated quality costs performed on the beverage technic in 2017 (See Table 3).

TABLE III. COMPARISON OF THE ACTUAL AND ESTIMATED QUALITY COSTS PERFORMED ON THE BEVERAGE TECHNIC IN 2017

1) Comparison with prior research: After comparing it with previous research, the researcher compared the study results by three other people's work. The results of the study are as follows:

- Based on the research conducted by Beverage Technic, the solution given is the opposite of the solution above, namely by reducing the initial cost of testing raw materials. The Company is spending too much on controlling the raw materials. However, the resulting defective products tend to be stagnant with the previous period. Control of raw materials by the Company is the cost of initial testing of raw materials and handling raw materials. Therefore, a reduction is needed because the Company's costs are not in line with its quality.

- The Beverage Technic tries to reduce the cost of valuation and the cost of internal failure. The company focus on the cost of preventing defective products 
through training. The expectation is to reduce the costs of internal failure, namely the cost of repacking and reworking costs so that production costs incurred by the Company become more efficient and do not need to reduce the selling price due to damaged / defective products. So that researchers reduce the cost of assessment and internal failure.

- Whereas the Beverage Technic has implemented a quality cost, but it does not report it separately but includes production cost as a company overhead. The Company applies prevention costs, valuation costs, and failure costs, but the costs incurred have not been efficient. Therefore, the Company should not spend that kind of cost and will impact on high production costs. These costs include the cost of production supervisors, the cost of initial testing of raw materials, product inspection costs, repacking, and reworking.

2) Benefits obtained by the company: The company can analyze the relationship between the types of quality costs. For example, in reducing the cost of failure, it is necessary to increase the cost of valuation and prevention costs to know each cost's effectiveness. Based on the quality costs analysis, the Company has the highest proportion of valuation costs than other costs. This condition happens because the Company is more focused on detecting errors in its production process to find out the cause and provide solutions.

The purpose of the quality cost system is to provide a tool for facilitating quality programs and quality improvement activities Quality. It can indicate the health of management performance in many areas of the organization. Measurements of quality-related costs also reveal shortcomings in cost allocation, standards, procedures, and practices which may remain undetected by the more commonly used production/operation and labour based analysis [9].

Based on the analysis of quality costs, companies can determine how much the actual costs incurred for product quality control. Then the Company can track the cost efficiency that occurs and can provide a policy on whether to make the reduction or not.

On the Beverage Technic, quality costs are part of the Company's production costs, so that changes in quality costs will impact changes in production costs. Suitable quality control activities may reduce production costs and efficiency. The analysis of quality costs by reducing unnecessary costs may reduce production costs. It also able to make an impact on management to allocate quality, effectively, and efficiently cost. If the cost of quality decreases, its production costs can be reduced, and company profits will increase. However, as mentioned earlier, this quality cost improvement requires continuous action or evaluation to become even better.

\section{CONCLUSION AND SUGgestion}

- Beverage Technic has not implemented quality costs as a quality control tool for the products produced. The Company only arranges production costs and includes some costs for its quality into production costs so that the quality costs become hidden and enter into overhead items.

- Beverage Technic has not reported quality costs, so it has not done the calculation, classification, and making quality cost reports. The Company includes the cost of quality into the Company's production costs.

- Based on the calculations, the total percentage of quality costs to reach $4.03 \%$ of total sales means the Company incurs costs that are too large than the standard costs $(2.5 \%)$. After applying quality costs, total quality costs reduced to $2.16 \%$ of total sales with the composition of preventive costs of $1.04 \%$, valuation costs of $0.68 \%$, and internal failure costs of $0.44 \%$.

\section{REFERENCES}

[1] A. Chopra and D. Garg, "Behavior patterns of quality cost categories," The TQM Journal, vol. 23, no. 5, pp. 510 - 515, 2011

[2] D.R. Hansen and M.M. Mowen, Managerial Accounting, Edition 8, Book 1. Jakarta: Salemba Empat, 2009.

[3] S.B. Jaju, R.P. Mohanty, and R.R. Lakhe, "Towards managing quality cost: a case study," Total Quality Management \& Business Excellence, vol. 20, no. 10, pp. 1075-1094, 2009.

[4] M.N. Nasution, Manajemen Mutu Terpadu Edisi 3. Jakarta: Penerbit Ghalia Indonesia, 2015.

[5] A. Schiffauerova and V. Thomson, "A review of research on the cost of quality models and best practices," International Journal of Quality and Reliability Management, vol. 23, no. 6, pp. 647-669, 2006

[6] R.H. Garrison, E.W. Noreen, P.C. Brewer, and R.U. Mardini, Managerial accounting. New York: McGraw-Hill/Irwin, 2003, p. 800.

[7] E.J. Blocher, K.H. Chen, and T.W. Li, Cost management: A strategic emphasis (ed.). New York, NY: McGraw Hill International, 2002.

[8] S. Sturm, G. Kaiser, and E. Hartmann, "Long-run dynamics between cost of quality and quality performance," International Journal of Quality \& Reliability Management, vol. 36, no. 8, pp. 1438-1453, 2019.

[9] A. Chopra and B.J. Singh, "Unleashing a decisive approach to manage quality costs through behavioural investigation," Business Process Management Journal, vol. 21, no. 6, pp. 1206-1223, 2015. 